\title{
Temperature and maturation stage: its effects on the germination of Jatropha seeds ${ }^{1}$
}

\author{
Leandro Mariano da Silva ${ }^{2}$, Ricardo Felicio ${ }^{2}$, Frederico da Costa Mendes Silva², \\ Ivan Carneiro Custódio ${ }^{2}$, Patrícia Souza da Silveira², Fábio Santos Matos²
}

\begin{abstract}
The present study had as objective to identify the adequate maturation stage for fruit harvest as well as the ideal temperature for germination of Jatropha curcas seeds. The fruit were collected to form a composite sample, and then classified by color in three maturity stages as follows: Stage I - yellow fruit with shiny black seeds; Stage II - yellow fruit, with more than $50 \%$ brownish black, and shiny black seeds; Stage III - dry black fruit with matt black seeds. Subsequently, evaluations of the degree of moisture, germination, electrical conductivity and water absorption at different temperatures $(20,25,30,35$ and $40{ }^{\circ} \mathrm{C}$ ). The study followed a $3 \times 5$ factorial experimental design with four replications. The maximum germination occurs at a temperature of $35^{\circ} \mathrm{C}$, it is recommended to harvest the seeds of Jatropha curcas at maturity stage II.
\end{abstract}

Index terms: physiological quality, oil seed, uniformity.

\section{Temperatura e estádio de maturação: seus efeitos na germinação de sementes de pinhão manso}

\begin{abstract}
RESUMO - O presente estudo teve como objetivo identificar o adequado estádio de maturação para colheita de frutos bem como a temperatura ideal para germinação de sementes de pinhão manso. Os frutos foram colhidos de forma aleatória para compor uma amostra composta. Após a colheita, estes frutos foram classificados de acordo com a coloração, em três estádios de maturação que constituíram os seguintes tratamentos: Estádio I: frutos amarelos, com sementes pretas brilhantes; Estádio II: frutos amarelos, com mais de 50\% em tom marrom escuro, com sementes pretas brilhantes; Estádio III: frutos pretos e secos, com sementes pretas foscas. Posteriormente, foram realizadas avaliações do grau de umidade, germinação, condutividade elétrica e absorção de água nas diferentes temperaturas $\left(20,25,30,35\right.$ e $\left.40^{\circ} \mathrm{C}\right)$. O delineamento experimental foi o esquema fatorial $3 \times 5$ com quatro repetições. O máximo de germinação ocorre na temperatura de $35^{\circ} \mathrm{C}$, recomenda-se colher as sementes de pinhão manso no estádio II de maturação.
\end{abstract}

Termos para indexação: qualidade fisiológica, sementes oleaginosas, uniformidade.

\section{Introduction}

Global warming caused by pollutant emissions and increasing greenhouse effect have raised worldwide concern for environment preservation and strengthened the agenda for partial or total replacement of fossil fuels by biofuels. Producing biofuel through the exploration of energetic plant species figures as a feasible sustainable alternative, given the diversity of existing oleaginous species and the reduction in pollutant emissions that they provide. The search for sustainable energetic alternatives requires evaluation of renewable sources that bring about minor impact on the environment.

Brazil has great potential for production of biofuels in most of its territory due to its edaphoclimatic aspects, biodiversity, land and manpower availability, as well as proven technical competence in the field of agricultural sciences (Matos et al., 2014).

The country plays a leading role in world forums on clean energy and has approximately $40 \%$ of its electric grid powered by renewable sources, such as sugar cane biomass $(15.5 \%)$, firewood and charcoal (8.1\%), hydropower (11.5\%), biodiesel and other renewable sources (4.1\%). The other $60 \%$ come from non-renewable sources, such as petrol (39.4\%), uranium (1.3\%), natural gas (13.5\%), mineral coal (5.7\%), and others (0.6\%) (MME, 2015). The National Program for Production and Use of Biodiesel (PNPB) has been fostering

${ }^{1}$ Submitted on 07/12/2016. Accepted for publication on 11/10/2016.

${ }^{2}$ Universidade Estadual de Goiás, Campus Ipameri, 75780-000 - Ipameri, GO, Brasil.

*Corresponding author <leandro.agroueg@outlook.com> 
production of that fuel, in order to partially replace oil diesel by gradually mixing it with biodiesel. Law 13.033, of $24^{\text {th }}$ September 2014, made compulsory the addition of $7 \%$ of biodiesel to the oil diesel distributed throughout Brazilian oil refineries (ANP, 2016). The installed capacity for biodiesel production authorized to operate commercially reached 7.3 million cubic meters per year in October 2015 (Portal Brasil, 2016). However, PNPB has relied solely on a single raw material, soybean. Therefore, diversifying the production of raw material is necessary, in order to make the system less vulnerable to weathering conditions, and to generate wealth and promote social inclusion in oleaginous plant producing regions through the introduction of promising species like physic nut.

Physic nut (Jatropha curcas L.) is a perennial monoecious species of the Euphorbiaceae family, the same one that includes castor bean, cassava and rubber tree. Physic nut seeds contain 30 to $40 \%$ of oil that can be processed into biodiesel (Parawira, 2010). Oil produced by these seeds has high content of oleic acid, yielding highly stable biodiesel for trade in regions with mild and tropical climates (Martins et al., 2010). The oil and paste are used to produce soap, and the shrub can be found fencing small rural lands in Brazil. Physic nut also has medicinal properties, and its latex is used to heal external wounds. The leaves and nuts are highly purging, and their consumption in great amounts can cause human death (Araújo and Sousa, 2008). Despite its high economic potential, the species still lacks basic agronomic information to ensure stable productivity and revenue to producers.

Physic nut fruit maturation occurs unevenly within the same and different inflorescence periods over virtually six months a year, which mobilizes considerable manpower and is likely to result in high costs. Uneven fruit maturation yields seeds (unripe, ripe and dry) with different physiologic characteristics. Thus, research studies are required in order to reduce manpower costs and recommend ideal harvesting times that will yield seeds with optimal physiologic quality (Pessoa et al., 2012).

The germination test applied to evaluate the physiologic quality of seeds from cultivated plants does not have methodology designed specifically for physic nut. So, ideal fruit maturity and temperature are still to be determined, as they directly affect uniformity of germination and speed of biochemical reactions (Martins et al., 2008; Pascuali et al., 2012). Therefore, the present study was designed to determine and recommend ideal maturity stage for fruit harvesting and optimal temperature for germination of physic nut seeds.

\section{Materials and Methods}

The study was carried out in the Plant Physiology Laboratory of Goiás State University (UEG), Ipameri Campus, Ipameri, Goiás state, between May and August 2015. Physic nut fruit were randomly collected from plants aged 1 year old in UEG experimental field in order to form a compound sample. After harvest, the fruit were classified by color in three maturity stages as follows: Stage I - yellow fruit with shiny black seeds; Stage II - yellow fruit, with over 50\% brownish black, and shiny black seeds; Stage III: dry black fruit with matt black seeds.

\section{Seed biometry}

Biometric characterization of seeds was accomplished with 25 seeds in four replication, and morphometric features were measured with a digital $0.01 \mathrm{~mm}$-precision pachymeter (ZAAS Model) in the following evaluations: length (longest dimension), longest diameter (perpendicular to length), and shortest diameter (from rafis and perpendicular to length), values being recorded in $\mathrm{mm}$ (Pessoa et al., 2012).

\section{Water content}

Water content $(\%)$ was determined in an oven at $105{ }^{\circ} \mathrm{C}$ during 24 hours. Two replicates were used with whole physic nut seeds placed in tared containers capped with aluminum lids. After that period, the containers were taken out of the incubator and placed in a desiccator to reach room temperature (Brasil, 2009).

\section{Germination test}

Germination test was carried out following the completely randomized design, with 100 seeds (four 25 -seed replications) in each sample distributed onto germination test paper rolls, imbibed with distilled water to 2.5 times the weight $(\mathrm{g})$ of dry paper. Rolls were placed in sealed plastic bags, in order to prevent excessive loss of water, and taken to a BOD-type incubator (Marconi 403) set to temperatures of 20, 25, 30, 35 and $40{ }^{\circ} \mathrm{C}$ without lighting time. Two germination counts were accomplished at five and eight days, respectively, following the recommendations of Brasil (2009).

\section{Water absorption test}

In order to determine water absorption, the samples were soaked in distilled water and stored in a BOD incubator at temperatures of $20,25,30,35$ and $40{ }^{\circ} \mathrm{C}$ for 12 hours. $20 \mathrm{~g}$ of seeds were placed in a $200 \mathrm{~mL}$ plastic container holding $80 \mathrm{~mL}$ of distilled water at 4:1 mass ratio. After hydration, the samples were taken out of the containers and placed on 
filtering paper during two minutes for removal of surface water (Chaves et al., 2012). The content of absorbed water was determined by means of the following equation:

$$
\mathrm{U}^{*}=\mathrm{M}_{\mathrm{e}}-\mathrm{M}_{\mathrm{s}} / \mathrm{M}_{\mathrm{s}}
$$

Where,

$\mathrm{U}^{*}$ : product water content (decimal b.s.)

Me: mass after absorption $(\mathrm{kg})$

Ms: product dry mass $(\mathrm{kg})$

Statistical analysis

Data were subjected to variance analysis and, in cases where F test presented significant results, Newman-Keuls tests were carried out for multiple comparisons of the samples averages (both with $\mathrm{p}<0.01$ ). These statistical analyses were accomplished using software SISVAR 5.3 (Ferreira, 2011).

\section{Results and Discussion}

Studies focusing on morphologic analyses of seeds may help to understand the germination process and determine vigor and viability of physic nut. Biometric knowledge of seeds is essential for the development of precision agriculture that applies machinery and proper facilities for production storage (Christo et al., 2012).

Table 1 shows the results related to seed length, width, thickness and weight. Differences in length, width and weight can be seen between maturity stages.

Seeds from Maturity Stage I presented higher length values compared to those from the other maturity stages, but there were no statistical differences from Maturity Stage II. Stages I and II presented equal values for variables width and thickness, differing only from Stage III. However, seeds from Stage III presented lower values for all the variables analyzed. Seed moisture content tests were carried out, and results

Table 1. Comparison of average length, width, thickness and weight of 25 physic nut seeds based on their fruit maturity stage (I: yellow fruits with shiny black seeds; II: yellow fruits with over $50 \%$ dark brownish with shiny black seeds; III: dry black fruits with pale black seeds).

\begin{tabular}{ccccc}
\hline $\begin{array}{c}\text { Maturity } \\
\text { stage }\end{array}$ & $\begin{array}{c}\text { Length } \\
(\mathrm{mm})\end{array}$ & $\begin{array}{c}\text { Width } \\
(\mathrm{mm})\end{array}$ & $\begin{array}{c}\text { Thickness } \\
(\mathrm{mm})\end{array}$ & $\begin{array}{c}\text { Weight } \\
(\mathrm{g})\end{array}$ \\
\hline I & $20.50 \mathrm{a}$ & $11.00 \mathrm{a}$ & $9.00 \mathrm{a}$ & $29.75 \mathrm{a}$ \\
II & $20.00 \mathrm{a}$ & $11.00 \mathrm{a}$ & $9.00 \mathrm{a}$ & $28.00 \mathrm{~b}$ \\
III & $18.75 \mathrm{~b}$ & $10.25 \mathrm{~b}$ & $8.50 \mathrm{a}$ & $18.50 \mathrm{c}$ \\
\hline CV $(\%)$ & $2.53 *$ & $2.69 *$ & $3.77^{\mathrm{ns}}$ & $1.97 *$ \\
\hline
\end{tabular}

*Significant at $1 \%$ by $\mathrm{F}$ test, ${ }^{\text {ns }}$ Non-significant, averages followed by the same letter did not differ by Newman Keuls test at $1 \%$ significance. varied among maturity stages. Stage I reached the highest moisture content $(41.91 \%)$, followed by Stage II (37.74\%) and Stage III (6.63\%).

The absence of differences in seed length, width and thickness at Stages I and II is a result of the short time span between them, and the lower seed weight at Stage II compared to I is possibly related to reduced water supply. The low values of the same variables in seeds from Stage III are a result of reduced moisture content in them, as they were in final desiccation phase. According to Pessoa et al. (2012), water content is an efficient parameter for determining ideal harvesting time.

Analysis of water absorption by physic nut seeds showed differences between temperatures and maturity stages, the coefficient of variation being $8.44 \%$. Table 2 shows the average values of water absorption by physic nut seeds at three different maturity stages and five distinct temperatures. Regardless of temperature, Maturity Stage III presented the highest values of water absorption, and regardless of maturity stage, water absorption increased with higher temperatures.

Regardless of temperature, water absorption was higher in seeds collected at Maturity Stage III due to low water potential of seeds that have gone through natural desiccation. Greater water absorption by seeds at all phenologic stages following increasing temperature may be connected to aquaporin activity. Reduction in temperature alters cytosolic $\mathrm{pH}$ and inhibits and/or reduces aquaporin activity (Heinen et al., 2009; Taiz and Zeiger, 2013).

Table 3 shows the results of the first and second counts of physic nut seed germination test at different maturity stages and temperatures. The coefficients of variation were 24.90 and $21.61 \%$, respectively. In the first count, the highest germination percentages occurred at 30 and $35^{\circ} \mathrm{C}$. For Stages I and II, the highest values were achieved at $35{ }^{\circ} \mathrm{C}$ and for Stage III, at $30{ }^{\circ} \mathrm{C}$. At $20^{\circ} \mathrm{C}$, no germination occurred in any stage, and at 25 and $40^{\circ} \mathrm{C}$, seeds presented low germination percentages. In the second count, the highest values remained within temperatures 30 and $35^{\circ} \mathrm{C}$, the latter standing out with higher values for Stages I and II. At $30^{\circ} \mathrm{C}$, Stage III had the highest germination percentage.

In this study, temperatures equal to or lower than $25^{\circ} \mathrm{C}$ and higher than $40{ }^{\circ} \mathrm{C}$ impaired germination of physic nut seeds, which occurs because such temperatures are out of the optimal range for germination, between 25 and $35^{\circ} \mathrm{C}$. These results corroborate those found by Pascuali et al. (2012). Both in the first and second count, the germination test indicated that the seeds collected at Stages I and II presented higher germination percentages under $35{ }^{\circ} \mathrm{C}$. According to Rubio et al., 2013, seeds achieve better quality at maturity when 
Table 2. Water absorption of physic nut seeds (decimal b.s) at different temperatures and maturity stages (I: yellow fruits with shiny black seeds; II: yellow fruits with over 50\% dark brownish with shiny black seeds; III: dry black fruits with pale black seeds).

\begin{tabular}{cccccc}
\hline \multicolumn{7}{c}{ Water absorption } \\
\hline Maturity & $20^{\circ} \mathrm{C}$ & $25^{\circ} \mathrm{C}$ & $30{ }^{\circ} \mathrm{C}$ & $35^{\circ} \mathrm{C}$ & $40{ }^{\circ} \mathrm{C}$ \\
\hline I & $0.12 \mathrm{cA}$ & $0.14 \mathrm{cA}$ & $0.15 \mathrm{cA}$ & $0.14 \mathrm{cA}$ & $0.17 \mathrm{cA}$ \\
II & $0.19 \mathrm{bC}$ & $0.19 \mathrm{bC}$ & $0.20 \mathrm{bC}$ & $0.28 \mathrm{bB}$ & $0.36 \mathrm{bA}$ \\
III & $0.46 \mathrm{aC}$ & $0.59 \mathrm{aB}$ & $0.46 \mathrm{aC}$ & $0.71 \mathrm{aA}$ & $0.71 \mathrm{aA}$ \\
\hline $\mathrm{CV}(\%)$ & & & 8.44 & & \\
\hline
\end{tabular}

Lowercase letters (columns) indicate significant differences among maturity types; uppercase letters (rows) express significant temperature differences by Newman Keuls test at $1 \%$ significance.

Table 3. First and second counts of germination tests of physic nut seeds at different temperatures and maturity stages (I: yellow fruits, with shiny black seeds; II: yellow fruits with $50 \%$ in dark brown color, with shiny black seeds; III: dry black fruits with pale black seeds).

\begin{tabular}{|c|c|c|c|c|c|}
\hline \multicolumn{6}{|c|}{ First count $(\%)$} \\
\hline Maturity & $20^{\circ} \mathrm{C}$ & $25^{\circ} \mathrm{C}$ & $30^{\circ} \mathrm{C}$ & $35^{\circ} \mathrm{C}$ & $40^{\circ} \mathrm{C}$ \\
\hline $\mathrm{I}$ & $0.0 \mathrm{aE}$ & $35 \mathrm{cC}$ & $57 \mathrm{bB}$ & $71 \mathrm{bA}$ & $17 \mathrm{bD}$ \\
\hline II & $0.0 \mathrm{aE}$ & $50 \mathrm{bC}$ & $63 \mathrm{bB}$ & $91 \mathrm{aA}$ & $31 \mathrm{aD}$ \\
\hline III & $0.0 \mathrm{aE}$ & $62 \mathrm{aC}$ & $90 \mathrm{aA}$ & $75 \mathrm{bA}$ & $18 \mathrm{bD}$ \\
\hline CV (\%) & \multicolumn{5}{|c|}{24.90} \\
\hline \multicolumn{6}{|c|}{ Second count $(\%)$} \\
\hline I & $0.0 \mathrm{aC}$ & $35 \mathrm{cB}$ & $72 \mathrm{bA}$ & $77 \mathrm{bA}$ & $29 \mathrm{aB}$ \\
\hline II & $0.0 \mathrm{aE}$ & $50 \mathrm{bC}$ & $71 \mathrm{bB}$ & $96 \mathrm{aA}$ & $34 \mathrm{aD}$ \\
\hline III & $0.0 \mathrm{aD}$ & $71 \mathrm{aB}$ & $91 \mathrm{aA}$ & $89 \mathrm{aA}$ & $42 \mathrm{aC}$ \\
\hline
\end{tabular}

Lowercase letters (columns) indicate significant differences among maturity types; uppercase letters (rows) express significant temperature differences by Newman Keuls test at $1 \%$ significance.

they still hold high water contents. The seeds from Stage III presented higher germination percentage under $30{ }^{\circ} \mathrm{C}$, results that corroborate Carvalho and Nakagawa (2000), who consider this temperature ideal for several species. No germination occurred at $20^{\circ} \mathrm{C}$, regardless of the maturity stage, probably due to the fact that this temperature is lower than that recommended for species originating in tropical environments and adapted to high temperatures (Dias et al., 2012). At temperatures 25 and $30{ }^{\circ} \mathrm{C}$, satisfactory germination results were achieved with Stage III seeds, corroborating Oliveira et al. (2014).

At $40{ }^{\circ} \mathrm{C}$, germination rates decreased, which might have been caused by higher temperature compared to that recommended for the species.

Maturity stage I did not present satisfactory results as to germination, which can be explained by the fact that seeds had not achieved physiologic maturity and temperatures lower than $25{ }^{\circ} \mathrm{C}$ and higher than $35^{\circ} \mathrm{C}$ impair germination for being outside the recommended range for most species.

\section{Conclusions}

The maximum germination percentage of physic nut seeds occurs at $35^{\circ} \mathrm{C}$.

Harvesting of physic nut seeds for obtaining maximum germination potential is recommended at Maturity Stage II, with yellow fruits presenting $50 \%$ of brownish black capsules and shiny black seeds

\section{References}

ANP- Agência Nacional de Petróleo. Biodiesel - Introdução. www.anp. gov.br/?pg=73292\&amp;m=\&amp;t1 Accessed on: Feb. $10^{\text {th }}, 2016$.

ARAÚJO, L.G.; SOUSA, K.C.I. Pinhão manso para produção de biodiesel. Revista Anhanguera, v.9, n.1, p.95-119, 2008. http://pos. anhanguera.edu.br/wp-content/uploads/2015/07/cap_05_2008.pdf

BRASIL. Ministério da Agricultura, Pecuária e Abastecimento. Regras para análise de sementes. Ministério da Agricultura, Pecuária e Abastecimento. Secretaria de Defesa Agropecuária. Brasília: MAPA/ACS, 2009. 395p. http://www.agricultura.gov.br/arq_editor/ file/2946_regras_analise_sementes.pdf 
CARVALHO, N.M.; NAKAGAWA, J. Sementes: ciência tecnologia e produção. Jaboticabal: FUNEP. 2000. 588 p.

CHAVES, T.H.; RESENDE, O.; SIQUEIRA, V.C.; ULLMANN, R. Qualidade fisiológica das sementes de pinhão manso (Jatropha curcas L.) durante o armazenamento em três ambientes. Semina: Ciências Agrárias, v.33, n.5, p.1653-1662, 2012. http://www.uel.br/ revistas/uel/index.php/semagrarias/article/view/7677

CHRISTO, L.F.; AMARAL, J.F.T.D.; LAVIOLA, B.G.; MARTINS, L.D.; AMARAL, C.F. Biometric analysis of seeds of genotypes of physic nut (Jatropha curcas L.). Agropecuária Científica no Semiárido, v.8, n.1, p.1-3, 2012. http://www.alice.cnptia.embrapa. $\mathrm{br} / \mathrm{handle} / \mathrm{doc} / 926368$

DIAS, L. A. S.; MISSIO, R.F.; DIAS, D.C.F.S. Antiquity, botany, origin and domestication of Jatropha curcas (Euphorbiaceae), a plant species with potential for biodiesel production. Genetics and Molecular Research, v.11, n.3, p.2719-2728, 2012. http://www. funpecrp.com.br/gmr/year2012/vol11-3/pdf/gmr2043.pdf

FERREIRA, D.F. Sisvar: a computer statistical analysis system. Ciencia e Agrotecnologia, v.35, n.6, p.1039-1042, 2011. http://www.scielo.br/ scielo.php?script=sci arttext\&pid=S1413-70542011000600001

HEINEN, R.B.; YE, Q.; CHAUMONT, F. Role of aquaporins in leaf physiology. Journal of Experimental Botany, v.60, p.2971-2985, 2009. https://jxb.oxfordjournals.org/content/early/2009/06/19/jxb.erp171.full

MARTINS, C.C.; MACHADO, C.G. ; CAVASINI, R. Temperatura e substrato para o teste de germinação de sementes de pinhão-manso. Ciência e Agrotecnologia, v.32, n.3, p.863-868, 2008. http://www. scielo.br/pdf/cagro/v32n3/a24v32n3.pdf

MARTINS, L.D.; TOMAZ, M.A.; AMARAL, J.F.T.; LAVIOLA, B.G.; BORCANE, M. Desenvolvimento inicial de mamona e pinhão-manso em solo submetido a diferentes corretivos e doses de fósforo. Revista Verde, v.5, n.1, p.143-150, 2010. http://www.gvaa. com.br/revista/index.php/RVADS/article/view/254

MATOS, F.S.; CARVALHO, D.D.C.; SOUZA, A.C.; NEVES, T.G.; RIBEIRO, R.P.; CRUVINEL, C.K.L.; ROSA, V.R., SANTOS, P.G. F. Viabilidade agronômica do consórcio entre pinhão manso e soja. Revista Agrarian, v.7, n.24, p.226-232, 2014. http://www.periodicos. ufgd.edu.br/index.php/agrarian/article/viewArticle/2262
MME- Ministério de Minas e Energia. Resenha Energética Brasileira. http://www.mme.gov.br/documents/1138787/1732840/ Resenha+Energ\%C3\%A9-tica+-+Brasil+2015.pdf/4e6b9a34-6b2e48fa-9ef8-dc7008470bf2 . Accessed on: Feb. 29 2016.

OLIVEIRA, G.L.; DIAS, D.C.F.S.; HILST, P.C.; SILVA, L.J.D.; DIAS, L.A.S. Standard germination test in physic nut (Jatropha curcas L.) seeds. Journal of Seed Science, v.36, n.3, p.336-343, 2014. http://www.scielo.br/ scielo.php?script=sci arttext\&pid=S2317-15372014000300009

PARAWIRA, W. Biodiesel production from Jatropha curcas: A review. Scientific Research and Essays, v.5, p.1796-1808, 2010. http://www.academicjournals.org/article/article1380634226 Parawira.pdf

PASCUALI, C.L.; SILVA, F.S.; PORTO, A.G.; SILVA FILHO, A.; MENEGHELLO, G.E. Germinação de sementes de pinhão manso em diferentes temperaturas, luz e substratos. Semina: Ciências Agrárias, v.33, n.4, p.1435-1440, 2012. http://www.uel.br/revistas/ uel/index.php/semagrarias/article/view/7180

PESSOA, A.M.S.; MANN, R.S.; SANTOS, A.G.; RIBEIRO, M.L.F. Influência da maturação de frutos na germinação, vigor e teor de óleo de sementes de pinhão-manso (Jatropha curcas L.). Scientia Plena, v.8, n.7, p. 1-11, 2012. http://www.scientiaplena.org.br/sp/ article/view/407

PORTAL BRASIL. http://www.brasil.gov.br/economia-eemprego/2016/01/alta-da-producao-de-biodiesel-em-2015-eprojetada-em-17-5\#. Accessed on: Feb.29 ${ }^{\text {th }}, 2016$

RUBIO, F.; MENEGHEL, A.P.; GOMES, L.F.S.; MALAVASI, M.M. Stages of maturation of the fruit on germination and oil content in seeds of Jatropha curcas Lin. Semina: Ciências Agrárias, v.34, n.2, p.663-668, 2013. http://www.uel.br/revistas/uel/index.php/ semagrarias/article/view/8862

TAIZ, L.; ZEIGER, E. Fisiologia vegetal. 5.ed. Porto Alegre: Artmed, 2013. 954p. 